\title{
The Tubing Destruction Features in Operation of the Gas Condensate Fields with Corrosive Fluids High Content
}

\author{
Nazarii Chaban, Valentyn Myndiuk, Oleg Karpash \\ Energy Department, National Technical University of Oil and Gas, Ivano-Frankivsk, Ukraine \\ Email address: \\ nazarii.chaban@gmail.com (N. Chaban), tinlaven@gmail.com (V. Myndiuk), karpash@nung.edu.ua (O. Karpash)

\section{To cite this article:} \\ Nazarii Chaban, Valentyn Myndiuk, Oleg Karpash. The Tubing Destruction Features in Operation of the Gas Condensate Fields with \\ Corrosive Fluids High Content. International Journal of Fluid Mechanics \& Thermal Sciences. Vol. 3, No. 6, 2017, pp. 75-81. \\ doi: $10.11648 /$ j.ijfmts.20170306.13
}

Received: March 20, 2017; Accepted: April 13, 2017; Published: January 16, 2018

\begin{abstract}
This of article is devoted to solving the problem of determining the actual mechanism of corrosion caused by the influence of corrosive environment with high pressures and temperatures on the tubing pipe metal, during high depth condensate fields development, with a high content of hydrogen sulfide and carbon dioxide in the fluid. The of results of the actual state evaluation of tubing pipe specimens are presented, the causes and nature of the corrosion damages and the mechanisms of their progress in the given conditions are identified. In particular, the of results of visual and instrumental investigation shows, that corrosion of the tubing surface has local (zone) nature; corrosion processes occurs as on interior as well on exterior tubing surface, whereby interior surface has the presence of corrosion deposits in local zones and also pitch zones, and exterior surface corrosion is present only by pitch corrosion. The local corrosion on the tubing surface is caused by carbon dioxide carrion. The main impact factor is the presence in gas-liquid mixture the molecules of $\mathrm{CO}_{2}$ and $\mathrm{H}_{2} \mathrm{CO}_{3}$ and ions $\mathrm{HCO}_{3}{ }^{-}$and $\mathrm{HCO}_{3}{ }^{2-}$, as a result of carbon dioxide gas dissolving, which activate the environment corrosive aggressiveness.
\end{abstract}

Keywords: Tubing, Gas Condensate Fields, High Depth, Corrosion Damages, High Corrosion Fluid

\section{Introduction}

Analysis of the tubing pipes' corrosion mechanism while transportation of corrosive-active products showed the dependence of the process on the degree of salinity and production well flooding, flow rate, corrosive components content, the spontaneous combination of which had different effects on the rate and nature of the pipe corrosion damages. The objective technical evaluation of tubing pipes in various stages of operation is the indispensable forecasting prerequisite for ensuring the optimal management of industrial safety and reliability of extractive processes. The existing range of methods to assess the actual technical state of the tubing pipes are designed for the effective detection of retirement defects, applying the method of quantitative comparison of the measured parameters with the regulatory ones, but do not involve intermediate control measures of properties and tubing pipes' metal structure in cases of their long-term contact with a corrosive environment, as well as do not allow to assess the safety margin of corrosion-damaged pipes, the possibility of their further operation, and the potential residual life depending on the corrosiveness of downhole environments.

Well operation practice at condensate fields, with great depth of the productive horizon (average depth of 5400-5500 m) and high corrosiveness of environment and fluids, showed that one of the main reasons for the decline of hydrocarbon production volumes is tubing pipes' breakdowns. The main factors that lead to tubing pipes' breakdowns is a significant landed depth, high reservoir temperature and products corrosiveness.

Another one factor that reduces the tube columns run time is a hydrochloric acid treatment of wells for their productivity intensification and bottom-hole treatment. However, despite its obviousness, this approach is very simplistic. In fact, tubing pipes and pipelines are exposed to various influences, which vary both in time and in space. The progress of localized corrosion is caused not only by transported fluids aggressiveness, but also by gas-liquid flow field structure, the applied pipe material type, steel microstructure as well as mechanical and corrosion characteristics of the pipes' material. Corrosion damages to the inner and outer surface of the tubing pipes and pipelines, pipes' mechanical damages during the installation work are often appeared as the main causes of 
pipelines accidents, in according to $[1,2]$.

The character of a representative pipe corrosion damages in these conditions, which are typical for condensate fields of

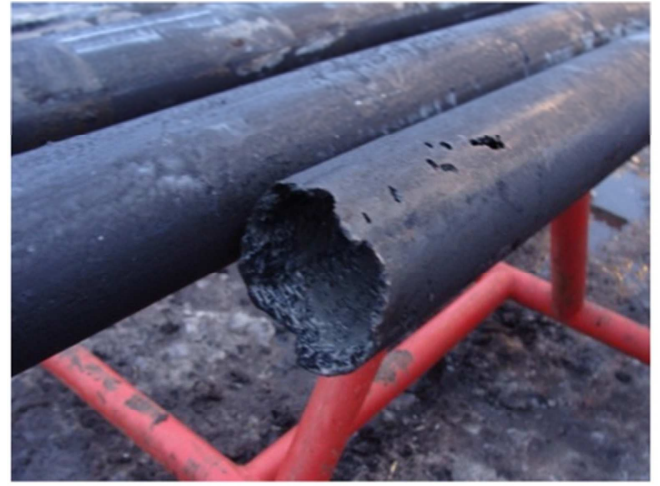

a) private corporation "Naftohazvidobuvannya", Ukraine, are given in Figure 1.

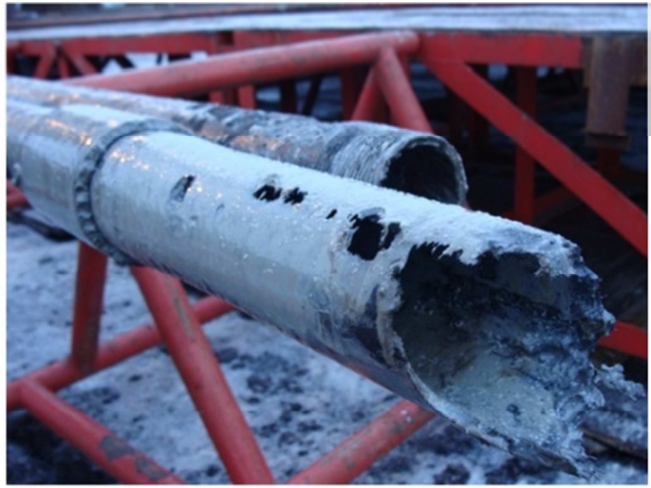

b)

Figure 1. The general view of the typical tubing pipe corrosion damages $(a, b)$ resulting of operation condensate fields by private corporation "Naftohazvydobuvannya", Ukraine.

\section{The Procedure and Results of Diagnostic and Technical State Control of Tubing Pipes}

\subsection{The Tubing Pipes Damages Types and Methods of Diagnostics}

A considerable number of different factors affecting the tubing pipes, as well as various kinds of work, carried out in the well, cause the existing character of actual slip load. Specificity of tubing pipes operating conditions results in a string buckling failure, movements, sliding deformation, deterioration and destruction, which are unacceptable in operation. Buckling failure and concomitant changes in the structure of pipe metal occur in cases, when the slip load reaches its critical values. All this help to reveal about the tendency of tubing pipes to the accumulation processes of fatigue damages in the metal structure, leading to a sharp decrease of bearing capacity and service time of the pipes [4].

Tubing strings are exposed to both static by its own weight and variable cyclic loads, the variety of which leads to the various deteriorations and destructions.

While tubing parted, there is a significant reduction in flow rate (so-called parametric failure), as well as shutdown (functional failure). Additionally, the [5, 9] and data analysis of maintenance and repair work in deep wells showed that the average well life time up to parametric failure is two years, and in some cases, the operating time period was less than 10 months. Thus, considerable number of the wells operate with significantly reduced production rate.

The existing procedures of diagnostic and technical state control of tubing pipes generally are regulated by GOST R 53366 - 2009 [3], and are applied for the determination the applicability for the further tubing pipes operation. While metering, the inspection and sorting work (grading) are conducted, divided into two phases:

1) visual defects detection;

2) defects detection by using different types of control and measurement (non-destructive testing, compression test, parameter measurement by specific control devices, calibration testing).

Overview of diagnostic methods, procedures for the inspection of technical condition and predicting of corrosionfatigue condition of the tubing string has shown that the existing regulations governing the conducting of inspection activities on tubing pipes, do not contain the phase for the determination of the tubing string pipe steels fatigue strength under low-cycle loading both in air and in aggressive saline corrosive environments, which, certainly, is important in the calculation of resource indicators and evaluation of tubing corrosion-fatigue state.

For a more detailed analysis of characteristics, causes and consequences of active aggressive destruction of pipes and a research of assessing the true technical state of their specimens, operated in conditions of gas condensate fields deep-sunk wells, the authors carried out a complex of activities, which includes: visual-optical inspection with measuring the size of the revealed surface defects, actual values' measurements of the physical-mechanical characteristics using the methods of non-destructive testing and associated technical means, as well as metallographic examination to determine the actual values of the parameters and the state of the steel pipes microstructure.

\subsection{The Results of Visual and Instrumental Inspection}

For the experimental research two specimens were chosen - tubing pipes' segments with nominal diameter $73 \mathrm{~mm}$, which properties are regulated by GOST 633-80 [6].

The list of controlled parameters and corresponding technical means is shown in the Table 1 . 
Table 1. Controlled parameters and technical means for their measurement.

\begin{tabular}{|c|c|c|c|}
\hline № & Controlled parameter & Technical control means & Regulatory document or control procedure \\
\hline 1 & Presence and type of surface defect & Surveillance magnifier LPK-471 (2x) & RD 34.10.130-96 Instruction on visual and measuring testing \\
\hline 2 & Size of surface defects & $\begin{array}{l}\text { Toolbar L-300; slide gauge SC-II-125- } \\
0,05 \text { with depth gauge }\end{array}$ & RD 34.10.130-96 Instruction on visual and measuring testing \\
\hline 3 & $\begin{array}{l}\text { Surface layer hardness according to } \\
\text { Brinell hardness scale }\end{array}$ & $\begin{array}{l}\text { Dynamic hardness tester TD-32, impact- } \\
\text { resonance hardness tester TKR-35 }\end{array}$ & $\begin{array}{l}\text { GOST } 22761-77 \text { Metals and alloys. Brinell Hardness Test } \\
\text { Method by portable static hardness tester }\end{array}$ \\
\hline 4 & Coercitive strength $\mathrm{Hc}, \mathrm{A} / \mathrm{cm}$ & Structurescope KRM-C-K2M & Operation manual as a part of equipment package \\
\hline 5 & $\begin{array}{l}\text { Impact strength } \mathrm{KCV} \text { at a } \\
\text { temperature of } 0{ }^{\circ} \mathrm{C}, \mathrm{J} / \mathrm{cm} 2\end{array}$ & Data-measuring system, IVS-I2 & $\begin{array}{l}\text { Procedure of impact strength measurements for pipeline steels } \\
\text { (developed by Research and Scientific Institute of Petroleum } \\
\text { Engineering, 2011) }\end{array}$ \\
\hline 6 & $\begin{array}{l}\text { Material electrical resistance, } \\
\text { microOhm }\end{array}$ & $\begin{array}{l}\text { Microhmmeter } \\
\text { BSZ-010-2 }\end{array}$ & $\begin{array}{l}\text { Procedure of yield strength measurement for structural } \\
\text { (pipelines) steels (developed by Research and Scientific } \\
\text { Institute of Petroleum Engineering, 2011) }\end{array}$ \\
\hline 7 & Pipe wall thickness, $\mathrm{mm}$ & Ultrasonic thickness gauge УТ-31 & Operation manual as a part of equipment package \\
\hline
\end{tabular}

The results of visual and instrumental inspection proved, that corrosion on the surface oh tubing pipes has local (zone) nature, corrosion processes occur as on interior as on exterior pipe surface, whereby interior surface has the presence of corrosion deposits in local zones and also pitch zones, and exterior surface corrosion is present only as pitch corrosion. Exterior pipe surface is fully corrosive, general corrosion is coupled with local corrosion zones, damaged with pitch corrosion, in some places causing to occurrence of perforation damages.

General view and sizes of the defects are given in Figure 2.

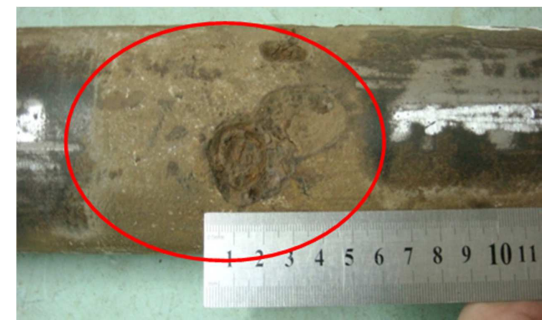

(a) local corrosion cavity, full depth $3 \mathrm{~mm}$

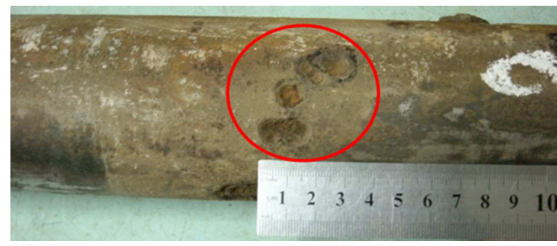

(b) local corrosion cavities, full depth $3,2 \mathrm{~mm}$

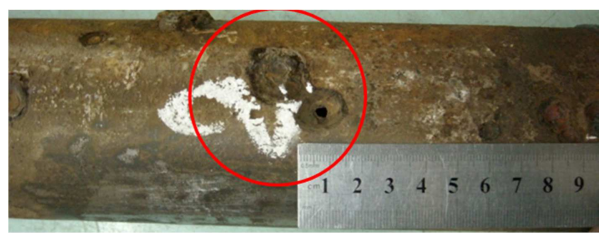

(c) local corrosion cavities with perforation defect diameter $3 \mathrm{~mm}$

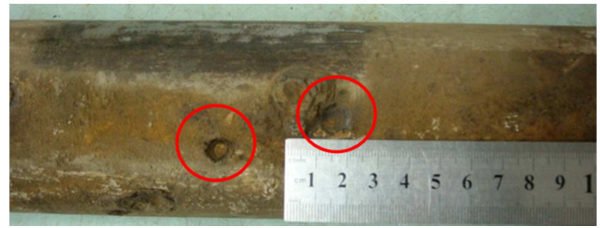

(d) local corrosion cavities of size 8 and 12, full depth $2 \mathrm{~mm}$

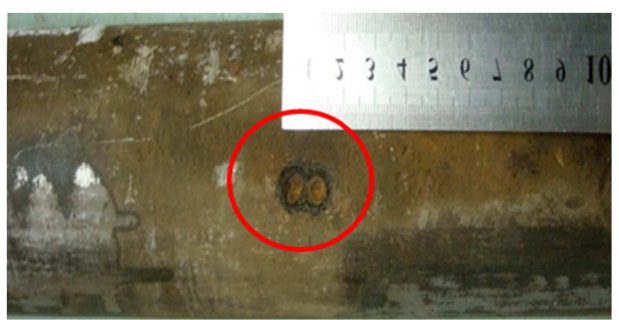

(e) local corrosion cavities of size $8 \mathrm{~mm}$, depth 1,8 mm

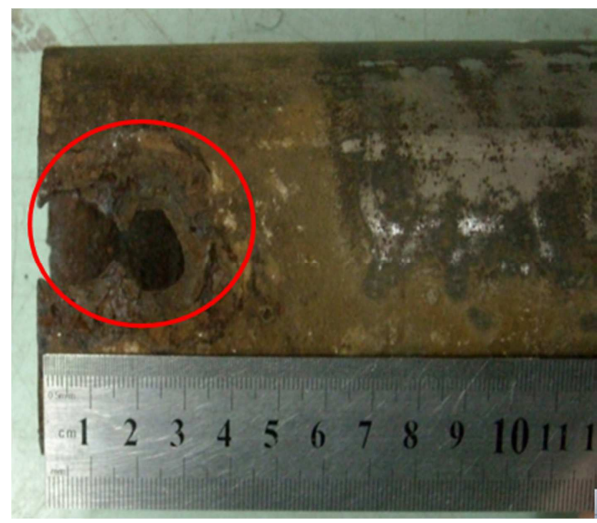

(f) corrosion perforation defect of length $40 \mathrm{~mm}$

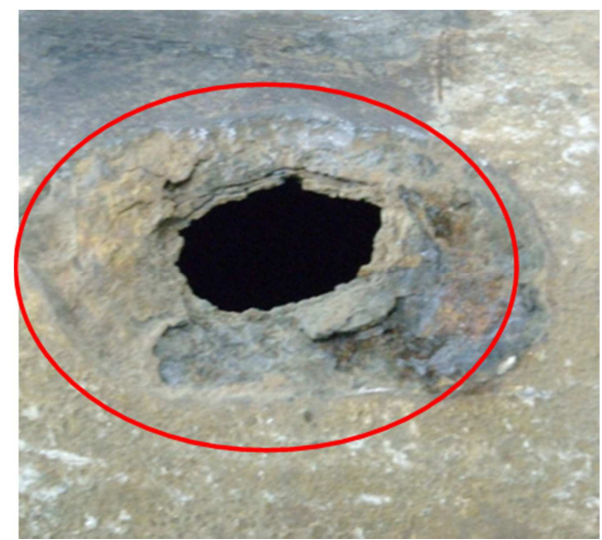

(g) Corrosion perforation defect; effective zone $35 \mathrm{~mm}$, relative mesh dimension $12 \mathrm{~mm}$

Figure 2. The results of the visual and measuring tubing inspection.

The results of the instrumental and dimensional inspection are given in Table 2 
Table 2. Results of the instrumental and dimensional inspection.

\begin{tabular}{llllllll}
\hline $\begin{array}{l}\text { №. of } \\
\text { specimen }\end{array}$ & $\begin{array}{l}\text { Brinell } \\
\text { hardness scale } \\
(\mathbf{H B})\end{array}$ & $\begin{array}{l}\text { Ultimate tensile } \\
\text { strength (UTS) } \\
(\mathbf{M P a})\end{array}$ & $\begin{array}{l}\text { Yield } \\
\text { strength } \\
(\mathbf{M P a})\end{array}$ & $\begin{array}{l}\text { Impact strength } \\
\text { according to Charpy } \\
(\mathbf{K C V}) \text { at } \mathbf{0}^{\circ} \mathbf{C}(\mathbf{J} / \mathbf{c m} \mathbf{)})\end{array}$ & $\begin{array}{l}\text { Electrical } \\
\text { resistance } \\
(\boldsymbol{\mu} \mathbf{O} \text { Ohm) }\end{array}$ & $\begin{array}{l}\text { Coercivity } \\
(\mathbf{A} / \mathbf{c m})\end{array}$ & $\begin{array}{l}\text { Pipe wall } \\
\text { thickness, mm }\end{array}$ \\
\hline 1 & 246,8 & 824,9 & 668,6 & 14,3 & 34,2 & 12,83 & 5,2 \\
2 & 247,8 & 826,5 & 669,9 & 14,2 & 33,9 & 12,69 & 5,3 \\
\hline
\end{tabular}

Hardness indexes represented, that given pipe samples belong to hardness group $\mathrm{M}$. The increased coercivity value is a characteristic of steels after thermal or thermomechanical treatment. There were no great deviations in pipe wall thickness (indicated values up to $0.3 \mathrm{~mm}$ ), that is the evidence of spilly pipe metal and local corrosion damages soundness. Low ductility pipe metal is the evidence of low impact strength, which can cause to occurrence and growth of resistant and corrosion cracks in particular operation conditions.

\subsection{The Results of Metallography}

Metallography results indicate the exceeding perlite part in the microstructure, the ferrite component focused on grain boundaries of perlite, causing uneven thickness of intergranular boundaries. The different grain size and uneven distribution of perlite in the bulk alloy are indicated. Metallography results verified the high value of measured coercivity.

The results of microstructure phases measurements are given in Table 3.

Table 3. Results of microstructure phases measurements.

\begin{tabular}{llllll}
\hline NO of specimen & $\begin{array}{l}\text { Ferrite fraction } \\
(\mathbf{F e}), \boldsymbol{\%}\end{array}$ & $\begin{array}{l}\text { Perlite fraction } \\
(\mathbf{P e}), \boldsymbol{\%}\end{array}$ & $\begin{array}{l}\text { Average (Pe) grain } \\
\text { diameter by Fere, } \boldsymbol{\mu m}\end{array}$ & $\begin{array}{l}\text { Average (Fe) grain } \\
\text { diameter by Fere, } \boldsymbol{\mu m}\end{array}$ & $\begin{array}{l}\text { Ra tio } \\
\boldsymbol{\mu m}\end{array}$ \\
\hline 1 & 17,56 & 74,58 & 24,75 & 11,25 \\
2 & 12,00 & 80,70 & 49,63 & 9,42 \\
\hline
\end{tabular}

\subsection{The Methods and Results of the Corrosion Products Research}

To determine the type of corrosion on tubing pipes and prevailing factors that caused it, the research of corrosion products was conducted. Research works of corrosion products phase composition, crystalline and magnetic microstructures has been made. The interior and exterior surfaced pipe samples were carried out for the corrosion causes determination.

Research of materials phase composition and crystalline were held by using diffractometer DRON-3.0 with radiation of copper anode.

Research of magnetic microstructure was held by using Mössbauer spectroscopy performed by spectrometer MS-1104Em using isotope ${ }^{57} \mathrm{Co}$ in the $\mathrm{Cr}$ matrix with activity $50 \mathrm{mC}$. Isomer shift calibration was performed with relation to $\alpha$-Fe.

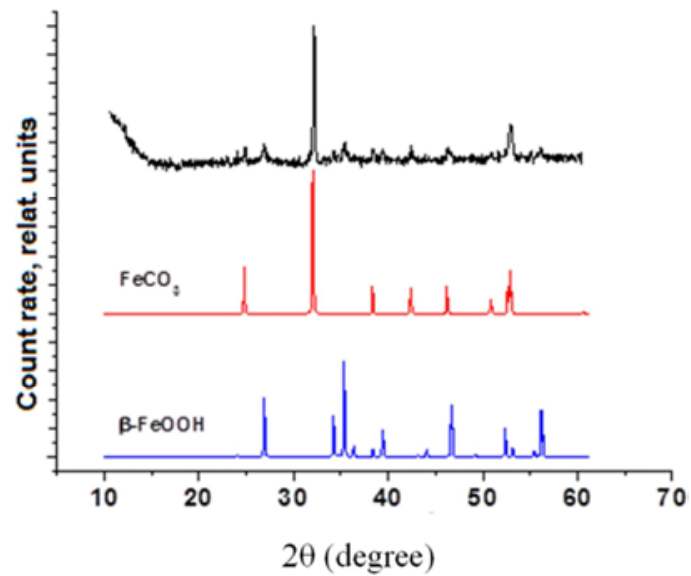

Figure 3. XRD pattern of corrosion products on interior tubing surface, and calibration XRD patterns of $\mathrm{FeCO}_{3}$ and $\beta$ - $\mathrm{FeOOH}$ phases.
Analysis of corrosion products phase composition, received from deposits on the interior tubing surface, showed the presence of two phases of the material (Figure 3). The reflexes, corresponding the crystalline phases $\mathrm{FeCO}_{3}$ and $\beta$ $\mathrm{FeOOH}$ are clearly identified on the XRD pattern.

Mössbauer researches verified the results, obtained by Xray analysis. Mössbauer spectrum of corrosion products, obtained from deposits on the interior tubing surface (Figure 4), is approximated with three doublet lines. Parameters of one of them identically match the ion of $\mathrm{Fe}^{2+}$, which are in the structure of $\mathrm{FeCO}_{3}$. The relative contribution of this component in the integrated intensity of the Mössbauer spectrum is $48 \%$. The other two doublet lines, characterized by similar values isomer shift $\delta$ and excellent value of the quadrupole splitting $\AA$, correspond to the ions $\mathrm{Fe}^{3+}$, located in two non-equivalent positions in the crystal structure of $\beta$ $\mathrm{FeOOH}$.

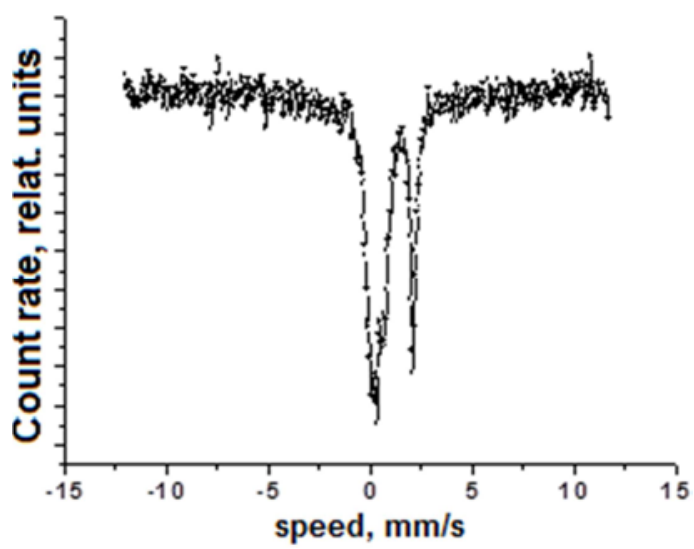

Figure 4. Mössbauer spectrum of corrosion products on the interior tubing surface. 
X-ray analysis of corrosion products from pits on the exterior tubing surface of the investigated pipe specimens identified the presence of ferrohydrate (Figure 5). Low intensity broad reflexes, presented on the XRD pattern, identify the low degree of material crystallinity, which is characteristic for this phase. Iron ferrohydrate (also known as "amorphous iron oxide" or "aqueous iron oxide") is a unstable polymorphic modification iron hydroxide, widespread in natural conditions, which eventually turns into a more stable phase of gothite $(\alpha-\mathrm{FeOON})$ and hematite $\left(\alpha-\mathrm{Fe}_{2} \mathrm{O}_{3}\right)$. Ferrohydrate is the simplest form of o iron xidation; the crystal lattice is represented by $\mathrm{Fe}_{5} \mathrm{O}_{8} \mathrm{H} \cdot \mathrm{H}_{2} \mathrm{O}, \quad \mathrm{Fe}_{5} \mathrm{O}_{8} \cdot 4 \mathrm{H}_{2} \mathrm{O}$ or $\mathrm{Fe}(\mathrm{OH})_{3}$. Ferrohydrate equilibrium reaction depends on the environment $\mathrm{pH}$ and in case of low crystallinity described as follows:

$$
\mathrm{Fe}(\mathrm{OH})_{3}+3 \mathrm{H}^{+} \leftrightarrow \mathrm{Fe}^{3+}+3 \mathrm{H}_{2} \mathrm{O}
$$

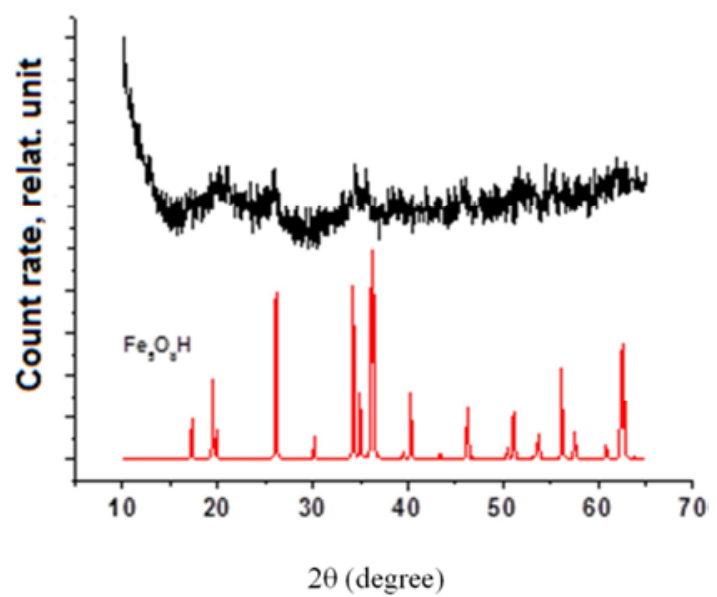

Figure 5. XRD-pattern of corrosion products on external tubing surface.

Mössbauer spectrum of corrosion products on the exterior tubing surface (Figure 6) is approximated by two doublet lines, meeting the resonant absorption $\gamma$--quanta by nuclei $\mathrm{Fe}^{3+}$. Two doublet lines correspond to two non-equivalent position of $\mathrm{Fe}^{3+}$ ions in octahedral $\left(\mathrm{Fe}_{2} \mathrm{O} \cdot \mathrm{OH}\right)_{6}$ and tetrahedral $\left(\mathrm{Fe}_{2} \mathrm{O} \cdot \mathrm{OH}\right)_{4}$ environments in the structure $\mathrm{Fe}_{5} \mathrm{O}_{8} \mathrm{H}$.

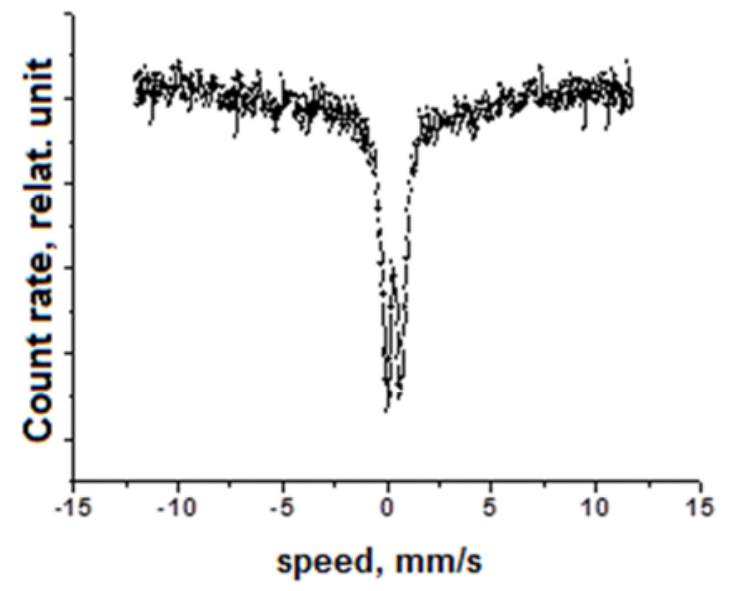

Figure 6. Mössbauer spectrum of corrosion products on the exterior tubing surface.
The tubing of local corrosion zones (local corrosion corrosion, which focuses on certain areas of the surface in the form of patches or pits) are caused by the flow of electrochemical processes on the tubing surface, such as passage of electric current between different areas of the pipe surface (anode and cathode). The galvanic corrosion occurs due to the action macro- and microhalvanic couplings in metal.

The occurrence of galvanic coupling in investigated pipe samples is caused by the presence of metal impurities, areas with different crystal structure (this fact was verified by the microstructure research), formation of pores in the oxide film, the presence of areas of different mechanical loads.

The presence of $\mathrm{FeCO}_{3}$ in corrosion products is caused by the influence of carbon dioxide gas $\mathrm{CO}_{2}$ on the processes of anodic dissolution of iron, so-called carbon dioxide or $\mathrm{CO}_{2}$ corrosion.

\section{Main Types and Causes of Corrosion}

Carbon dioxide corrosion is caused by the presence in situ water dissolved forms of carbon dioxide $\mathrm{CO}_{2}$ and their impact on the environment corrosion activity. Carbon dioxide in aqueous solution can be in dissolved form, in the forms of: dissolved $\mathrm{CO}_{2}$ gas in water, nondissociated molecules of carbonic acid $\mathrm{H}_{2} \mathrm{CO}_{3}$, hydrocarbonate ions $\left(\mathrm{HCO}_{3}{ }^{-}\right)$and carbonate ions $\left(\mathrm{CO}_{3}{ }^{2-}\right)$. In equilibrium conditions the balance is kept between all forms:

$$
\mathrm{CO}_{2}+\mathrm{H}_{2} \mathrm{O} \leftrightarrow \mathrm{H}_{2} \mathrm{CO}_{3} \leftrightarrow \mathrm{H}^{+}+\mathrm{HCO}_{3}^{-} \leftrightarrow 2 \mathrm{H}^{+}+\mathrm{CO}_{3}^{2-}
$$

Ration of the forms $\mathrm{CO}_{2} / \mathrm{HCO}_{3}{ }^{-} / \mathrm{CO}_{3}{ }^{2-}$ depends on environment $\mathrm{pH}$ :

when $\mathrm{pH}=4,3$ only molecules of $\mathrm{CO}_{2}$ and $\mathrm{H}_{2} \mathrm{CO}_{3}$ are present in water;

when $\mathrm{pH}=8,4$ only molecules of ions $\mathrm{HCO}_{3}{ }^{-}$are present in water;

when $\mathrm{pH}=12$ only molecules of ions $\mathrm{HCO}_{3}{ }^{2-}$ are present in water

The impact of carbon dioxide appears in two mechanisms:

(1) In case of high content of $\mathrm{CO}_{2}$.

Molecules of $\mathrm{H}_{2} \mathrm{CO}_{3}$ react directly with ions $\mathrm{Fe}$ :

$$
2 \mathrm{H}_{2} \mathrm{CO}_{3}+2 e^{-} \rightarrow \mathrm{HCO}_{3}^{-}+\mathrm{H}_{2}
$$

Reaction (2) is cathodic depolarization reaction:

$$
2 \mathrm{Fe}+2 \mathrm{H}_{2} \mathrm{CO}_{3} \rightarrow \mathrm{Fe}\left(\mathrm{HCO}_{3}\right)_{2}+\mathrm{H}_{2}
$$

As a result of reaction (4) soluble iron carbonate forms are formed.

(2) In case of low content of $\mathrm{CO}_{2}$ and high content of $\mathrm{HCO}_{3}{ }^{-}$by mineralization.

In this case the sequence of reactions with the formation of iron compounds occur:

$$
2 \mathrm{HCO}_{3}^{-}+2 e^{-} \rightarrow 2 \mathrm{CO}_{3}^{2-}+\mathrm{H}_{2}
$$

Reaction (5) is cathodic depolarization reaction. 


$$
\mathrm{Fe}+\mathrm{Fe}\left(\mathrm{HCO}_{3}\right)_{2} \rightarrow 2 \mathrm{FeCO}_{3}+\mathrm{H}_{2}
$$

As a result of reaction (6) low-solubility iron hydrocarbonate is formed.

In second case $\mathrm{H}_{2} \mathrm{CO}_{3}$ is donor of $\mathrm{H}^{+}$ions, spent in the cathodic reaction (5).

Ions $\mathrm{Fe}^{2+}$ interact with $\mathrm{HCO}_{3}{ }^{-} / \mathrm{CO}_{3}{ }^{2-}$ and $\mathrm{H}_{2} \mathrm{CO}_{3}$ forming $\mathrm{FeCO}_{3}$ :

$$
\begin{gathered}
\mathrm{Fe}^{2+}+\mathrm{CO}_{3}^{2-} \rightarrow \mathrm{FeCO}_{3} \\
\mathrm{Fe}^{2+}+\mathrm{HCO}_{3}^{-} \rightarrow \mathrm{FeCO}_{3}+\mathrm{H}^{+} \\
\mathrm{Fe}^{2+}+\mathrm{H}_{2} \mathrm{CO}_{3} \rightarrow \mathrm{FeCO}_{3}+2 \mathrm{H}^{+}
\end{gathered}
$$

With oxygen, dissolved in water, the reaction of iron dioxide forming occur:

$$
4 \mathrm{FeCO}_{3}+\mathrm{O}_{2} \rightarrow 2 \mathrm{Fe}_{2} \mathrm{O}_{3}+4 \mathrm{CO}_{2}
$$

As a result of reactions of the metal surface, the Solid iron carbonate sediments $\left(\mathrm{FeCO}_{3}\right)$, functioning as a barrier element by preventing the progress of corrosion process. Along with $\mathrm{FeCO}_{3}$ the formation of rust compounds $\mathrm{Fe}_{2} \mathrm{O}_{3} \cdot \mathrm{nH}_{2} \mathrm{O}$ and corrosion products of $\cdot \mathrm{FeCO}_{3}$ is possible.

Data analysis of X-ray inspection (Figure 5) and Mössbauer spectrography (Figure 6) indicate the soundness of carbon dioxide corrosion on the exterior tubing surface, as there are no direct contact of the metal surface and dissolved carbon dioxide gas, as a result, no iron carbonate $\left(\mathrm{FeCO}_{3}\right)$ is formed. Local pitch corrosion, in this case, is caused by the impact of galvanic couplings on the metal surface and forming the ferrohydrate phase according to the reactions:

$$
\begin{aligned}
\mathrm{Fe}(\mathrm{OH})_{3}+3 \mathrm{H}^{+} & \leftrightarrow \mathrm{Fe}^{3+}+3 \mathrm{H}_{2} \mathrm{O} \\
\mathrm{Fe}-2 e & =\mathrm{Fe}^{2+}
\end{aligned}
$$

The presence of $\mathrm{Fe}_{5} \mathrm{O}_{8} \mathrm{H}$ phase indicates the stages of corrosion progress, in this case as a result of electrochemical mechanism under the following scheme

$$
\begin{aligned}
\mathrm{Fe}^{2+} \rightarrow \mathrm{Fe}^{3+} \rightarrow \mathrm{Fe}(\mathrm{OH})_{2} & \rightarrow \mathrm{Fe}(\mathrm{OH})_{3} \rightarrow \mathrm{Fe}_{5} \mathrm{O}_{8} \mathrm{H} \rightarrow \beta-\mathrm{FeOOH} \rightarrow \alpha- \\
\mathrm{FeOOH} \rightarrow \alpha-\mathrm{Fe}_{2} \mathrm{O}_{3} & \rightarrow(13)
\end{aligned}
$$

This type of local corrosion can limit the potential number of widely used materials for oil and gas production [5, 8]. To solve the problems of corrosion damages, chemical inhibitors may be applied, though this decision involves a great number of technological limitations and loses while transporting of chemical reagents, etc.

Besides, in our case, we deal with more localized form of corrosion, pitting corrosion in particular, which occurs in $n$ difficult conditions in the presence of hydrocarbon in the environment of $\mathrm{CO}_{2}$ and $\mathrm{H}_{2} \mathrm{~S}$. In such a case, according to the gives results of tubing samples investigation, the unpredicted perforation damages of tubing pipes may occur [7 - 9].

Considering the above mentioned information, there is the need for selecting the materials, resistant to corrosion, impact pressure and temperature. The world practice in this case contains a number of general recommendations for materials selection, because this task is multicriterion and difficult for most of oil and gas companies in the world [10].

To select appropriate materials for tubing international experience [11] indicates the need for justification, based on industrial data for a specific field. It should start from the worst indicators for the operation - the highest operating pressure and temperature, the lowest $\mathrm{pH}$, the highest values of $\mathrm{CO}_{2}$ and $\mathrm{H}_{2} \mathrm{~S}$ in hydrocarbons and formation water mineralization.

Therefore, the purpose of further research is conducting a complex of field mechanical, fractographic, microscopic and chemical investigations of entire string (or more) pipes during the next plan overhaul in order to develop recommendations for the layout of corrosion-resistant tubing string to achieve minimal cost used, necessary reliability and accident-free operation of wells.

\section{Conclusion}

The results of visual and instrumental investigation shows, that corrosion of the tubing surface has local (zone) nature; corrosion processes occurs as on interior as well on exterior tubing surface, whereby interior surface has the presence of corrosion deposits in local zones and also pitch zones, and exterior surface corrosion is present only by pitch corrosion.

The local corrosion on the tubing surface is caused by carbon dioxide carrion. The main impact factor is the presence in gas-liquid mixture the molecules of $\mathrm{CO}_{2}$ and $\mathrm{H}_{2} \mathrm{CO}_{3}$ and ions $\mathrm{HCO}_{3}^{-}$and $\mathrm{HCO}_{3}{ }^{2-}$ as a result of carbon dioxide gas dissolving, which activate the environment corrosive aggressiveness. Factors that increase the corrosion progress on tubing pipes are concentration and partial pressure of $\mathrm{CO}_{2}, \mathrm{pH}$, temperature, presence of mineral impurities, flow structure, uneven microstructure and mechanical characteristics in the bulk volume of pipes metal. Carbon dioxide corrosion inhibition is a separate problem and may be investigated only by a detailed study of damaged pipes samples along the length of the string.

\section{References}

[1] N. Gafarov Determination of reliability and technical condition characteristics of equipment, operating in oil and gas fields, containing hydrogen sulfide / N. Gafarov, A. Honcharov, V. Kushnarenko. - M.: OJSC «Nedra Biznestsentr », 2001. - 239 p.

[2] V. Ivanov Basic principles of technical diagnostics and residual life determination of oil and gas objects equipment.: Study guide / V. Ivanov, A. Semneov, A. Gymadutdynov. Tyumen: TyumGNGU, 2005. $-50 \mathrm{p}$.

[3] GOST R 53366-2009. Steel pipes, used as casin and tubing for wells in oil and gas industry - Impl. 2010-03-01. - M: GosStandart: Standards Publishing Office, 2013.-195 p.

[4] B. Kopey, I. Kopey. Borehole pumping rods for oil production.-Ivano-Frankivsk: Fakel, 2009. - 406 p. 
[5] J. K. Brownlee, K. O. Flesner, K. R. Riggs. Selection and Qualitification of Materials for HPHT Wells. SPE 97590, 2005.

[6] GOST 633-80. Tubing pipes and couplings for them. Specification - Impl. 1983-01-01. - M: GosStandart: Standards Publishing Office, 1980. -30 p.

[7] European Federation of Corrosion Publications, No. 17. "A Working Party Report on Corrosion Resistant Alloys for Oil and Gas Production: Guidance on General Requirements and Test Methods for H2S Service” 2002.
[8] J. Kolts and S. Ciaraldi, "Corrosion Resistant Alloys in Oil and Gas Production", NACE, 1996.

[9] NACE Report 1F196, "Survey of CRA Tubular Usage", 1996.

[10] NACE Technical Report 1F192 (1993 Revision), Use of Corrosion Resistant Alloys in Oilfield Environments, NACE, Houston, TX, 1993.

[11] ISO15156/MR0175 Petroleum and natural gas industries Materials for use in $\mathrm{H}_{2} \mathrm{~S}$-containing environments in oil and gas production - Part 2: Cracking-resistant CRAs (corrosion resistant alloys) and other alloys. 